\title{
DIFFERENCES IN POSTPARTUM MATERNAL DEPRESSION LEVELS BASED ON CHARACTERISTICS OF MATERNAL AGE AND HUSBAND SUPPORT
}

\author{
Tisandra Safira Handini ${ }^{1}$, Nunik Puspitasari ${ }^{1}$ \\ ${ }^{1}$ Department of Biostatistics and Population \\ Faculty of Public Health, Airlangga University, Surabaya, Indonesia \\ Correspondence Address: Tisandra Safira Handini \\ E-mail: tisandrasafira@gmail.com
}

\begin{abstract}
The International Statistical Classification of Disease (ICD-10) defines postpartum depression as a mental and behavioral disorder that occurs after six-week labor. The number of postpartum blues in Asia is high and varies between 26-85\%. In Indonesia, especially Jakarta, Yogyakarta, and Surabaya, the prevalence of postpartum depression is 11$20 \%$. In Surabaya, 22\% mothers had postnatal depression in 2003. The occurrence of postpartum depression is influenced by several factors namely biological and characteristic. This study aimed to analyze differences in postpartum maternal depression levels based on characteristics of maternal age and husband support. This study used quantitative with cross sectional study design. The population of this study was 209 mothers with postpartum depression in the timeframe of 6 weeks to 1 year. The sample size was 70 samples selected through simple random sampling. The retrieval of data was through surveys and questionnaires. The results of the study showed most respondents aged 26-30 years had high husband support and were not at risk of depression. There was a significant difference between postpartum maternal depression levels based on maternal age $(\mathrm{p}=0.014)$ as well as on husband support $(\mathrm{p}=0.000)$. Based on the results, researchers suggest to establish continuous husband support, conduct early detection, and educate mothers.
\end{abstract}

Keywords: depression level, husband support, mother's age, postpartum depression

ABSTRAK

International Statistical Classification of Disease (ICD-10) mendefinisikan depresi postpartum sebagai gangguan mental dan perilaku yang terjadi setelah 6 minggu persalinan. Angka kejadian postpartum blues di Asia cukup tinggi dan sangat bervariasi antara 26-85\%, sedangkan angka kejadian postpartum blues di Indonesia, khususnya di kota Jakarta, Yogyakarta, dan Surabaya prevalensi depresi postpartum sebesar 11-20\%. Pada tahun 2003 di Surabaya, angka kemunculan gangguan depresi ibu pasca melahirkan sebesar 22\%. Terjadinya depresi pasca persalinan dipengaruhi oleh beberapa faktor yaitu ada faktor biologi dan faktor karakteristik. Penelitian ini bertujuan untuk menganalisis perbedaan tingkat depresi ibu pasca persalinan berdasarkan karakteristik umur ibu dan dukungan suami. Penelitian ini merupakan penelitian kuantitatif dengan rancangan penelitian cross sectional. Populasi penelitian ini yaitu ibu pasca persalinan selama periode 6 minggu sampai dengan 1 tahun sejumlah 209 orang. Besar sampel yaitu 70 sampel dipilih menggunakan simple random samping. Pengambilan data melalui survei dengan kuesioner. Hasil penelitian yaitu sebagian besar responden berusia 26-30 tahun; memiliki dukungan suami yang tinggi; dan tidak berisiko depresi. terdapat perbedaan yang signifikan antara tingkat depresi ibu pasca persalinan berdasarkan usia ibu $(p=0,014)$ dan terdapat perbedaan yang signifikan antara tingkat depresi ibu pasca persalinan berdasarkan dukungan suami ( $p=0,000)$. Dalam upaya menangani permasalahan tersebut, peneliti menyarankan agar para suami tetap memberikan dukungan yang maksimal, melakukan deteksi dini, serta meningkatkan pengetahuan $i b u$.

Kata kunci: tingkat depresi, dukungan suami, usia ibu, depresi pospartum

\section{INTRODUCTION}

Being a mother is every woman's right. Seeing their child born as their expectations is the happiest moment after labor. Fetus can be born naturally or through a process of surgery. Almost all women who are married and then pregnant go through labor. A substancial amount of preparation is needed to face the pre and postpartum period. 
All the preparations should be done well as it serves as part of the transition to motherhood.

However, there are also mothers who could not pass the period of postpartum adjustment of psychological, physical, or biological changes, resulting in the feeling of strong emotions. This could lead to feeling depression, which is also called the pospartum blues, later becoming postpartum depression if left untreated. International Statistical Classification of Disease (ICD-10) defines postpartum depression as a mental and behavioral disorder. Postpartum depression is a non-psychotic disorder that often appears 6 to 8 weeks after giving birth. However, another study states that postpartum depression appears 4 to 6 weeks after giving birth showing the characteristics of excessive anxiety, feeling depressed, weight changes, and insomnia (Restarina, 2017).

According to Kruckman (cited in Rusli, Meiyuntariningsih, and Warni, 2011), the emergence of depression after childbirth is caused by many factors including maternal characteristics and biological factors. Biological factors are the associated with hormonal changes during postpartum, and maternal characteristic factors are related to age. It is believed that age can affect the readiness to give birth, and the average age of readiness was 20-30 years as mothers are ready to support and care for their babies. According to paramedics, 20-30 years are the ideal age because the risk of facing medical complications is at its lowest (Slaoane and Bendict, 2009). Asia has a high number of postpartum blues incidents which vary in the range of 26 to $85 \%$. Indonesia has a postpartum blues incidence rate ranging from 50 to $70 \%$. Postpartum blues, if not handled properly, can cause postpartum depression and subsequently develop into psychosis after childbirth which will adversely affect both the baby and mother (Fitriana and Nurbaeti, 2016).
Taiwan conducted a study which found a $40 \%$ incidence of depression after mild to severe labor. Also found in other studies 18 of 40 women suffered from depression. The depression faced by women is in the form of behavior that cannot hold back feelings, have irritability, broken relationships with family, spouse/husband, friends and professionals. According to research in many countries, $50 \%-80 \%$ of primiparous mothers sufferred from postpartum blues, while moderate or severe postpartum depression or bipolar disorder is around 30-200 per 1,000 live births. The incidence of mild psychosis disorders is about 1 per 1,000 live births (Nazara, 2009). Globally, around $50-70 \%$ of all women after childbirth suffer from postpartum depression. About 50-70\% sufferred from postpartum depression with a sufficient amount varies from $5 \%$ to more than $25 \%$ after mothers gave birth in Indonesia (Fatmawati, 2015).

Postpartum depression harms the health of the child, mother, and family. Mothers who suffer from postpartum depression are less interested in their babies often not responding positively, for example when crying, making gestures, or eye contact. The mothers cannot properly care for their baby and becomes lazy in breastfeeding. The impact of mothers suffering from postpartum blues results in difficulty in making personal adjustments. While, babies can be fussy and easily hurt due to the mothers' unwillingness to breastfeed and poor care. Postpartum blues mothers also do not have the enthusiasm to breastfeed their babies resulting in development and growth being hindered. Babies breastfed by their mothers will have a better immune system compared to those not receiving breast milk.

According to Elvira (2006), internal factors that influence the occurrence of postpartum blues are maternal age, pregnancy under 20 and above 35 years of age, first birth/primipara, education, and readiness for new family members. The external factors 
include culture/habits of the community, husband's role, and family support. Mothers under 20 years old have a higher chance of postpartum blues compared those over 35 because they are not ready to adapt to the changes. Family support influences the readiness of the mother and family members to accept a new member. Husbands are especially important as they play provide support in the process of conceiving until the birth. Family economy and the lack of self confidence may bring hormonal changes in a mother after childbirth, thereby causing anxiety. It may cause a perception to kill her baby instead of living with hardships due to low family economic conditions. Mothers with low maternal education tend to have more children and are more likely to suffer postpartum blues as they cannot provide proper care. On the other hand, mothers with higher education will experience conflicting roles and social pressure between the obligation to work and to be a housewife. Symptoms of postpartum blues not followed up will become more severe and cause postpartum depression. For example, in Yogyakarta, Jakarta and Surabaya, the prevalence of postpartum depression was around 11 to $20 \%$ (Elvira, 2006). Research related to depression after childbirth was also conducted in Surabaya in 2003 and found that the number of depressive disorders after childbirth was around 22\% (Warsiki et al, 2003).

Risk factors for sociodemographic characteristics include the degree of prenatal and postnatal depression, a history of physical violence or intra-family exposure to violence, sex of newborn, the pregnancy experience, planned or unplanned pregnancy, and the family's psychiatric history. Based on the descriptions, it is necessary to conduct research related to differences in postpartum maternal depression levels according to the sociodemographic characteristics of mothers. Therefore, this study aimed to analyze differences in the level of postpartum maternal depression based on the characteristics of maternal age and husband support.

\section{METHODS}

This was a quantitative research conducting once at a time as it used a crosssectional design. It was conducted in 2 primary healthcare centers: Gading Primary Healthcare Center in Tambaksari sub-district and Simomulyo Primary Healthcare Center in Sukomanunggal sub-district in Surabaya. The research timeframe was between July to August 2019.

The population of this study were mothers who were in their period of 6 weeks to 1 year after birth. The population was 113 people in Gading Primary Healthcare Center and 96 people in Simomulyo Primary Healthcare Center. The samples were postdelivery mothers in the post labor of 6 weeks to 1 year who were willing to participate in the study. The sample size was then reduced to 70 postpartum mothers in Gading Primary Healthcare Center and Simomulyo Primary Healthcare Center. The number was obtained through simple random sampling and calculated using the Lemeshow formula.

The research independent variables included mother's age and husband support, and the dependent variable was the level of postpartum maternal depression. Data collection was carried out through translated questionnaires of Edinburgh Postnatal Depression Scale to measure the level of depression. The questionnaires consisted of 10 questions to describe the feelings of the mothers during 7 days after giving birth (Department of Health, 2005). While the questionnaires to measure husband support were adopted and modified from Asmayanti's (2017) research. All data generated were then analyzed by univariate and bivariate analyses.

This study has passed the ethical test as one of the data collection requirements. The ethics test was used to guarantee no 
ethical errors during data collection and ensure no disadvantaged parties in the research. Ethical testing became a requirement for research that involve human respondents. This research had received ethical approval by the Ethics Commission of the Faculty of Dental Medicine, Universitas Airlangga, with certificate number 424/HRECC.FODM/VII/2019.

\section{RESULTS}

\section{Postpartum Maternal Age Overview}

The age of the mothers referred to in this study were the age of the mother from birth to post-partum. Maternal age was classified into 5 age groups: less than 20 years, 20-25 years, 26-30 years, 31 - 35 years, and more than 35 years. Table 1 shows a frequency distribution table of maternal age after delivery.

Table 1. Frequency Distribution of Postpartum Mothers Age

\begin{tabular}{lcc}
\hline \multirow{2}{*}{ Age } & \multicolumn{2}{c}{ Quantity } \\
\cline { 2 - 3 } & n & \% \\
\hline Age $<20$ & 5 & 7.1 \\
\hline Age $20-25$ & 19 & $2 ., 1$ \\
\hline Age $26-30$ & 23 & 32.9 \\
\hline Age $31-35$ & 12 & 17.1 \\
\hline Age $>35$ & 11 & 15.7 \\
\hline Total & 70 & 100 \\
\hline
\end{tabular}

In accordance with Table 1, the majority of post-partum mothers was in the age group 26-30 years. This age group was classified as a young adult age group.

The 20-35 year group was the ideal age for marriage and childbirth. Women aged 20 years are ready to adapt when pregnancy occurs. Age of 20-35 years is low at risk during childbirth (Prihandini, Pujiastuti and Hastuti, 2016).

\section{Post-Natal Husband Support Overview}

The definition of husband support in this study was determined through constant husband presence, extra attention, and constant support when needed. This factor was measured through the wife's perception of the support given by her husband. Assessment of husband support factors were classified into three groups: low, moderate, and high. Table 2 presents a frequency distribution for support for postpartum mothers.

Table 2. Frequency Distribution of Postpartum Husband Support

\begin{tabular}{lcc}
\hline \multirow{2}{*}{ Husband's Support } & \multicolumn{2}{c}{ Quantity } \\
\cline { 2 - 3 } & $\mathbf{n}$ & $\mathbf{\%}$ \\
\hline Low & 2 & 2.9 \\
\hline Mid & 26 & 37.1 \\
\hline High & 42 & 60.0 \\
\hline Total & 70 & 100 \\
\hline
\end{tabular}

According to Table 2, the majority of postpartum mothers state that they were given high support by their husbands. The support of the mother includes the husbands' accompaniment, moral support, household work support, and attention after childbirth.

A husband support can reduce postpartum depression and act as a protector between potential stressers. Care-giving from the husband positively influences childbirth process and has been proven to be a significant preventative factor for postpartum depression (Yuliawan, Rahayuningsih, and Ambarwati, 2014).

\section{Postpartum Depression Maternal Levels Overview}

Postpartum depression is one of the major mental health disorders in postpartum mothers. The risk of depression was divided into 3 parts, such as no, moderate, and severe. Table 3 presents a frequency distribution of postpartum maternal depression levels. 
Table 3. Frequency Distribution of Postpartum Depression Mothers

\begin{tabular}{lcc}
\hline \multirow{2}{*}{ Depression Levels } & \multicolumn{2}{c}{ Quantity } \\
\cline { 2 - 3 } & n & \% \\
\hline No Risk & 42 & 60 \\
\hline Low Risk & 11 & 15.7 \\
\hline High Risk & 17 & 24.3 \\
\hline Total & 70 & 100 \\
\hline
\end{tabular}

Table 3 shows that a majority of postpartum mothers were not at risk of depression. Respondents could process feelings after labor and overcome all the problems due to changes after childbirth.

The stages in overcoming postpartum blues, sequentially, are self adjustment, coping with stress, and social support. The adjustment phase of women after childbirth goes through several phases, such as: 1) the take-in phase where the mother is very dependent on herself, 2) the taking hold phase, the transition that initially depends on independence (lasts for 3-10 days), 3) the phase of letting go for accepting responsibility with a new role (lasts for 10 days), and 4) the bounding attachment phase between mother and child (Ningrum, 2017).
Coping stress is the ability of mothers to cope with stressors after childbirth. There are 2 types of coping forms and functions, such as Problem Focused Coping (PFC) directed to reduce the demands of stressful situations and Emotion Focused Coping (EFC) directed to regulate emotional responses to pressing situations (Ningrum, 2017). Social support is a collection of social, emotional, cognitive, and behavioral processes that take place in a reciprocal interpersonal relationship. It consists of emotional support, assessment support, information support, instrumental support and the availability of social network (Yuliawan, Rahayuningsih and Ambarwati, 2014).

\section{Differences in Postpartum Depression Mothers Rates by Age}

Maternal age will be associated with the level of depression in postnatal mothers through the application of statistical tests. Table 4 presents the result of an analysis of the relationship between differences in postpartum maternal depression levels based on maternal age.

Table 4. Differences in Postpartum Depression Mothers Rates by Age

\begin{tabular}{|c|c|c|c|c|c|c|}
\hline \multirow{3}{*}{ Mother's Age } & \multicolumn{6}{|c|}{ Depression Levels } \\
\hline & \multicolumn{2}{|c|}{ No Risk } & \multicolumn{2}{|c|}{ Medium Risk } & \multicolumn{2}{|c|}{ High Risk } \\
\hline & $\mathbf{n}$ & $\%$ & $\mathbf{n}$ & $\%$ & $\mathbf{n}$ & $\%$ \\
\hline Age $<20$ & 0 & 0 & 1 & 9.1 & 4 & 23.5 \\
\hline Age $20-25$ & 10 & 23.8 & 3 & 27.3 & 6 & 35.3 \\
\hline Age $26-30$ & 14 & 33.3 & 5 & 45.5 & 4 & 23.5 \\
\hline Age $31-35$ & 12 & 28.6 & 0 & 0 & 0 & 0 \\
\hline Age $>35$ & 6 & 14.3 & 2 & 18.2 & 3 & 17.6 \\
\hline Total & 42 & 100 & 11 & 100 & 17 & 100 \\
\hline \multicolumn{7}{|c|}{$P=0,014$} \\
\hline
\end{tabular}

In Table 4 it can be seen that postpartum mothers aged 26-30 years (33.3\%) did not have a risk of depression; postpartum mothers aged 26-30 years $(45.5 \%)$ had a moderate risk of depression; whereas, postpartum mothers aged 20-25 years $(35.3 \%)$ were at risk of severe depression. The results of the statistical test show that there was a significant difference in 
the postpartum depression level by age $(\mathrm{p}=$ $0.014)$.

\section{Differences in Postpartum Depression Mothers Rates Based on Husband Support}

The mother's perception of the support provided by her husband will be linked to the level of postpartum depression in the mother through the application of statistical tests until a result is obtained. The following is an analysis of the relationship between differences in levels of postpartum depression based on husband's support.

Table 5. Differences in Postpartum Depression Mothers Rates Based on Husband Support

\begin{tabular}{lccccccc}
\hline \multirow{3}{*}{ Husband's Support } & \multicolumn{6}{c}{ Depression Levels } \\
\cline { 2 - 8 } & \multicolumn{2}{c}{ No Risk } & \multicolumn{1}{c}{ Medium Risk } & \multicolumn{3}{c}{ High Risk } \\
\cline { 2 - 7 } & $\mathbf{n}$ & $\mathbf{\%}$ & $\mathbf{n}$ & $\mathbf{\%}$ & $\mathbf{n}$ & $\mathbf{\%}$ \\
\hline Low & 0 & 0 & 0 & 0 & 2 & 11.8 \\
\hline Mid & 5 & 11.9 & 7 & 63.6 & 14 & 82.4 \\
\hline High & 37 & 88.1 & 4 & 36.4 & 1 & 5.9 \\
\hline Total & 42 & 100 & 11 & 100 & 17 & 100 \\
\hline & $P=0,000$ & & & & & \\
\hline
\end{tabular}

Based on Table 5, 37 postpartum mothers $(88.1 \%)$ with high husband support were not at risk of depression; mothers with low husband support $(63.6 \%)$ had a moderate risk of depression; while, mothers with moderate husband support people $(82.4 \%)$ had a risk of severe depression. Therefore, based on the statistical test, it could be said that there were significant differences in postpartum depression levels based on husband support $(\mathrm{p}=0.000)$.

\section{DISCUSSION}

Descriptive analysis found that a majority of the respondents were in the age group of 26-30 years. The majority stated that husband support was relatively high, and most respondents did not have the risk of depression. Whereas, the results of the bivariate analysis found that there were significant differences in the level of postpartum maternal depression based on maternal age and husband support.

\section{Differences in Postpartum Depression Mothers Rates by Mother Age}

There were some significant differences in the level of postpartum depression by age. Childbirth and pregnancy in adolescents became a supporting factor in the realization of postpartum blues. These results greatly affected the readiness of adolescent mothers. Adolescent readiness is defined as the readiness to be a mother, as well as financial, mental, physical, and social readiness (Henshaw, 2003).

Pregnant adolecents are more likely to suffer from Cephalopelvic Disproportion (CPD), hypertension of pregnancy, risk of giving birth to a baby with low birth weight (LBW), and anemia. Pregnant adolecents will have difficulty in accepting the stages of pregnancy because they are more likely to hide the pregnancy. Also, many pregnant teenagers do not receive prenatal care before their third trimester. The imagination of a healthy, funny, and doll-like baby is just a delusion because babies need care to grow and develop (Bobak, Lowdermilk and Jensen, 2005). 
In line with research from Kurniasari and Astuti (2015), there were some correlations between maternal age and risk for postpartum blues incidents. The Ahmad Yani Metro General Hospital in 2014 had an odds ratio value of 2,700 meaning that mothers with age at risk were 2,700 times more likely to experience postpartum blues. Another research also supports that the postpartum maternal age variable was less than 20 years $(\mathrm{p}=(0.000)<0.05)$ and an Rpvalue of 3.41 in which the postpartum maternal age of less than 20 years had a 3.41 times chance of suffering from postpartum blues than mothers over 20 years old (Fatmawati, 2015). Research by Prasetyo (2015) shows that there was a moderate correlation between maternal age and postpartum blues $(\mathrm{p}=0.001 ; \mathrm{r}=0.524)$. This shows that mothers under the age of 20 years and over 35 years were more at risk of experiencing postpartum blues. This result is supported by research by Pramudianti (2019), stating a significant relationship was found between the age of postpartum mothers and postpartum blues, and the value of the prevalence ratio was 5.75 (1.53-21.64). Therefore, it could be concluded that adolecents are 6 times more at risk of postpartum blues compared to the reproductive age of 20-35 years.

However, this study was different from the research of Hidayati (2017), discovering there was no correlation between age and postpartum blues $(\mathrm{p}=(0.138)>$ $0.05)$. Due to other aspects that influence postpartum blues, the level of maturity could not be determined by age alone.

Age is related to postpartum blues because age affects the health of the uterus. Age of under 20 years is vulnerable to care for a child, and mothers find it difficult to adapt and need help from health workers to accompany them through childbirth and hospital treatments. Having children at an old age increases burden, and thus mothers might face health concerns during childbirth. A woman's age during labor and pregnancy is often related to the mental readiness of becoming a mother. Mothers aged above 35 years also have risk of postpartum maternal due to fatigue and poor anatomical conditions of the body for childbirth and pregnancy. The age factor could not be changed, but it is possible to prevent postpartum depression through mature marriage which serves physically and mentally more stable state. Thus, the risk of postpartum depression could be avoided.

\section{Differences in Postpartum Depression Mothers Rate Based on Husband support}

There were some significant differences in postpartum depression rate based on husband support. These results are in line with research by Kurniasari and Astuti (2015) stating there was a significant correlation between husband support and postpartum blues events. Older respondents could be at risk and were 2,700 times more likely to suffer from postpartum blues. Research by Fatmawati (2015) show postpartum mothers who received moderate social support from husbands were 2.44 times more likely to suffer from postpartum blues $(\mathrm{p}=0.000 ; \mathrm{Rp}=2.44)$ than those who get high-level social support. There was a correlation between husband support and postpartum blues in primiparous mothers at Tugurejo District Hospital Semarang ( $\mathrm{p}=$ 0.033) (Fatimah, 2009).

This study by Hasanah (2017) shows there were several relationships of husband support during postpartum and family care ( $\rho$ $=0.036$ ). High support from husbands had resulted in low levels of depression after childbirth (Sumantri and Budiyani, 2015). This was proven from the negative relationship $(\mathrm{p}=-0.842)$ between husband support and postpartum depression. The results of the negative relationship show that higher husband support for postpartum mothers led to lower postpartum depression. 
Research by Fairus and Widiyanti (2014) shows there was a relationship between husband support and postpartum depression in Rumbia Primary Healthcare Center and Putra Rumbia Primary Healthcare Center in $2013(\mathrm{p}=0.000)$. A postpartum mother who did not get support from her husband has 6,013 chances of postpartum depression than a mother who received her husband support.

Husband as the closest person to wife must provide social support to accelerate healing and reduce the risk of complications or other disorders such as postpartum depression in women (Lyyra and Heikkinen, 2006). A lack of social support, especially from husbands, may cause high depression in women after childbirth. Inadequate husband support will cause women to feel unloved, inattentive, and ingnored. The postpartum period is a heavy adaptation process for women as mothers have new responsibilities and tasks (Marshall, 2004).

The support given by the husbands to the mothers after giving birth was quite high based on the assessment. Husband support can be in the form of spending time together during pregnancy to prevent loneliness, the ability to express her physical changes felt, and verbal and action motivation to increase comfort during pregnancy and post-delivery. Everyone close to pregnant women must be able to create a comfortable and safe atmosphere to provide motivation for positive thinking.

\section{CONCLUSION}

Based on the results in Gading Primary Healthcare Center and Simomulyo Primary Healthcare Center, the majority of postpartum mothers aged 26-30 years had high husband support and were not at risk of depression. There were some significant differences between the levels of postpartum maternal depression based on age. Postpartum mothers in the 26-30 age group had no risk of postpartum depression, while those in the 20-25 age group had a high risk. There was a significant difference between postpartum maternal depression levels based on husband support. Postpartum mothers were not at risk of depression when receiving high support from their husbands. However, there was a high risk of depression when mothers only received moderate support.

The authors suggest husbands to continue providing optimal support during pregnancy until delivery. Support could be in the form of spending time together, giving motivation and praise, and putting attention related to the changes. Husbands should conduct early detection of maternal conditions that show signs of postpartum depression. Early detection could start at pregnancy period by sharing feelings related to worries of pregnant women to prepare for the delivery process. Increasing knowledge of mothers related to the prevention and treatment of postpartum depression is also recommended. Knowledge could be delivered by healthcare workers, husbands, or be shared on social media. Mothers must be able to filter information, and thus the information obtained will not be a burden.

\section{REFERENCES}

Asmayanti (2017) Hubungan Dukungan Suami dengan Kejadian Depresi Postpartum di RSUD Panembahan Senopati Bantul Yogyakarta. Sekolah Tinggi Ilmu Kesehatan.

Bobak, I. M., Lowdermilk, D. L. and Jensen, M. D. (2005) Buku Ajar Keperawatan Maternitas. 4th edn. Jakarta: EGC.

Elvira, S. D. (2006) Depresi Pasca Persalinan. Jakarta: Balai Penerbit Fakultas Kedokteran Universitas Indonesia.

Fairus, M. and Widiyanti, S. (2014) 'Hubungan Dukungan Suami dengan Kejadian Depresi Postpartum pada Ibu Nifas', Jurnal Kesehatan Metro Sai Wawai, 7(1), pp. 11-18. 
Fatimah, S. (2009) Hubungan Dukungan Suami dengan Kejadian Postpartum Blues pada Ibu Primipara di Ruang Bugenvile RSUD Tugurejo Semarang. Universitas Diponegoro Semarang.

Fatmawati, D. A. (2015) 'Faktor Risiko yang Berpengaruh Terhadap Kejadian Postpartum Blues', Jurnal Edu Health, 5(2), pp. 82-93.

Fitriana, L. A. and Nurbaeti, S. (2016) 'Gambaran Kejadian Postpartum Blues pada Ibu Nifas Berdasarkan Karakteristik di Rumah Sakit Umum Tingkat IV Sariningsih Kota Bandung', Jurnal Pendidikan Keperawatan Indonesia, 2(1). doi: http://dx.doi.org/10.17509/jpki.v1i1. 2479.

Hasanah, U. (2017) 'Hubungan Dukungan Suami dalam Perawatan Masa Nifas dengan Kejadian Baby Blues', Jurnal Ilmu Keperawatan dan Kebidanan, III(2), pp. 56-116.

Henshaw, C. (2003) 'Mood Disturbance in The Early Puerperium: A Review', Archives of Women s Mental Health, 6(2), pp. 33-42. doi: https://doi.org/10.1007/s00737-0030004-X.

Hidayati, Y. (2017) Hubungan Usia dan Jenis Persalinan dengan Kejadian Postpartum Blues pada Ibu Post Partum di Wilayah Puskesmas Jetis II Kabupaten Bantul. Universitas 'Aisyiyah Yogyakarta.

Indonesian Ministry of Health (2005) The Edinburgh Postnatal Depression Scale (Translation-Indonesian). Western Australia: Department of Western Australia.

Kurniasari, D. and Astuti, Y. A. (2015) 'Hubungan antara Karakteristik Ibu, Kondisi Bayi dan Dukungan Sosial Suami dengan POstpartum Blues pada Ibu dengan Persalinan SC di Rumah Sakit Umum Ahmad Yani Metro Tahun 2014', Jurnal
Kesehatan Holistik, 9(3), pp. 115125. doi: https://doi.org/10.33024/hjk.v9i3.215

Lyyra, T. and Heikkinen, R. (2006) 'Perceived Social Support and Mortality in Older People', Journal of Gerontology: Social Sciences, 61(3), pp. 147-152. doi: https://doi.org/10.1093/geronb/61.3.S 147.

Marshall, F. (2004) Mengatasi Depresi Pasca Melahirkan. Jakarta: Arcan.

Nazara, Y. (2009) 'Efektivitas Psikoedukasi Terhadap Pencegahan Depresi Pascasalin (Penelitian di Pelayanan Kesehatan Kabupaten Nias, Sumatera Utara)', Maj Obstet Ginekol Indones, 33(4), pp. 216-223.

Ningrum, S. P. (2017) 'Faktor-Faktor Psikologis yang Mempengaruhi Postpartum Blues', PSYMPATHIC: Jurnal Ilmiah Psikologi, 4(2), pp. 205-218. doi: http://dx.doi.org/10.15575/psy.v4i2.1 589.

Pramudianti, D. N. (2019) 'Hubungan antara Usia Ibu Nifas dengan Kejadian Postpartum Blues', Journal of Midwifery and Reproduction, 2(1), pp. 13-18.

Prasetyo, T. D. (2015) Hubungan antara Usia Ibu dengan Kejadian Postpartum Blues di RSUD Panembahan Senopati Bantul Yogyakarta. Sekolah Tinggi Ilmu Kesehatan Jendral Achmad Yani Yogyakarta.

Prihandini, S. R., Pujiastuti, W. and Hastuti, T. P. (2016) 'Usia Reproduksi Tidak Sehat dan Jarak Kehamilan yang Terlalu dekat Meningkatkan Kejadian Abortus di Rumah Sakit Tentara Dokter Soedjono Magelang', Jurnal Kebidanan, 5(9), pp. 47-58. doi: http://dx.doi.org/10.31983/jkb.v5i10. 1147. 
Restarina, D. (2017) Gambaran Tingkat Despresi Ibu Postpartum di Wilayah Kerja Puskesmas Ciputat Timur Kota Tangerang Selatan Tahun 2017. Universitas Islam Negeri Syarif Hidayatullah.

Rusli, R. A., Meiyuntariningsih, T. and Warni, W. E. (2011) 'Perbedaan Depresi Pasca Melahirkan pada Ibu Primipara Ditinjau dari Usia Ibu Hamil', INSAN, 13(01), pp. 21-31.

Slaoane and Bendict (2009) Petunjuk Lengkap Kehamilan. Jakarta: Pustaka Mina.

Sumantri, R. A. and Budiyani, K. (2015) 'Dukungan Suami dan Depresi Pasca Melahirkan', InSight, 17(1), pp. 2938. doi: http://dx.doi.org/10.26486/psikologi. v17i1.682.

Warsiki, E. et al. (2003) 'Postnatal Depression in Three Hospitals in Surabaya', Folia Medica Indonesiana, 39(4), pp. 251-258.

Yuliawan, D., Rahayuningsih, F. B. and Ambarwati (2014) Pengaruh Dukungan Suami Terhadap Kesejahteraan Ibu Nifas di Wilayah Kerja Puskesmas Kecamatan Miri Kabupaten Sragen. Universitas Muhammadiyah Surakarta. 